\title{
Using an online survey to assess the spatial distribution of wild boar (Sus scrofa L.) crop damage and factors influencing this distribution and severity in Limburg province, Belgium
}

\author{
Anneleen Rutten ${ }^{1,2, *}$, Jim Casaer ${ }^{2}$, Thierry Onkelinx ${ }^{2}$, Lieven De Smet ${ }^{2}$, \\ Nele Witters ${ }^{3}$, Frank Huysentruyt ${ }^{2}$ \& Herwig Leirs ${ }^{1}$ \\ ${ }^{1}$ Evolutionary Ecology group, Department of Biology, University of Antwerp, \\ Universiteitsplein 1, B-2610 Antwerp, Belgium. \\ ${ }^{2}$ Wildlife management and invasive species unit, Research Institute for Nature and Forest (INBO), \\ Havenlaan 88 bus 73, B-1000 Brussels, Belgium. \\ ${ }^{3}$ Environmental Economics Group, Centre for Environmental Sciences (CMK), \\ Hasselt University, Martelarenlaan, B-3500 Hasselt, Belgium. \\ *Corresponding author: anneleen.rutten@uantwerpen.be
}

\begin{abstract}
Wild boar (Sus scrofa L.) reappeared in Flanders (northern Belgium) in 2006 after almost half a century of absence. Interactions between wild boar and human activities are frequent due to extensive fragmentation of the landscape in Flanders. Complaints about agricultural damage are increasing but the actual extent of crop damage remains unknown. The goal of this study was to assess the current risk and the spatial distribution of crop damage, as well as factors influencing damage distribution in the province of Limburg (eastern Flanders). An online survey was sent to farmers by email. Moreover, as we expected potential respondent bias towards farmers that already experienced damage, we also conducted a follow-up non-respondent check by telephone. Our study showed that the current crop damage probability on a farm lies between $42 \%$ (likely an overestimation due to respondent bias in the online survey) and 22\% (an underestimation based on the non-respondent check). There is considerable geographical variation in the proportion of farms that report boar damage; probability for crop damage due to wild boar is relatively high for farmers in Limburg but shows a geographically heterogeneous spread. Factors explaining the crop damage probability differed strongly between the online survey and the non-respondent check and no consistent results could be found. Our results show that using the online survey, it was possible to get an initial insight in the geographical distribution of crop damage. However, as we found differences between the results of the online survey and the non-respondent check, taking management decisions based solely on online survey results without conducting a non-respondent check could lead to misguided actions.
\end{abstract}

Keywords. Human-Wildlife Conflict, online survey, damage probability, respondent bias.

Rutten A., Casaer J., OnkelinX T., De Smet L., Witters N., Huysentruyt F. \& Leirs H. (2019). Using an online survey to assess the spatial distribution of wild boar (Sus scrofa L.) crop damage and factors influencing this distribution and severity in Limburg province, Belgium. Belgian Journal of Zoology 149 (1): 1-13. https://doi.org/10.26496/bjz.2019.26 


\section{Introduction}

The success of many wildlife populations depends on their capacity to coexist with humans (CARTER \& LINELL 2016). Resolving human-wildlife conflicts is therefore seen as a major challenge for conservation (TREVES et al. 2006). Species that re-establish in their former distribution area can typically be a source of conflict due to human safety risks or damage to crops, livestock, buildings, infrastructure, gardens, cars, etc. (TROUWBORST 2010). One such re-established species causing conflicts in Europe is the wild boar, Sus scrofa (Linnaeus, 1758; Mammalia, Chordata). Wild boar populations have been increasing all over Europe since the 1960s (SAEZ-ROYUELA \& TELlARIA 1986; BIEBER \& RUF 2005; ACAVEDO et al. 2007) and their expansion is still ongoing in most European countries (MASSEI et al. 2015). A combination of environmental and agricultural changes have triggered the revival of the wild boar, mainly due to 1- increased piglet survival due to rising winter temperatures and 2- a lower age of first reproduction and increased average litter size related to increasing food availability. The latter factor is caused by more frequent mast years, agricultural intensification, decrease of grasslands and an increase in rapeseed and maize cultivation (MASSEI et al. 2015; MORELLE et al. (2016).

The return of wild boar to Flanders (the northern part of Belgium) since 2006, after more than half a century of absence, rapidly developed from a few sightings to a now settled population. This is in line with the observed expansion in the rest of Europe (SCHEPPERS et al. 2014) and is of interest because of the intense intertwinement of urbanised, agricultural and natural areas leading to close contact of wildlife with human activities. Flanders is currently one of the most densely populated areas in Europe (462 persons per $\mathrm{km}^{2}$ ) (LiNELL et al. 2001). Forests represent a mere $11.4 \%$ of the total surface area (CASAER \& LICOPPE 2010; DEMOLDER et al. 2014) and the dense road network $\left(5.2 \mathrm{~km} / \mathrm{km}^{2}\right)$ results in highly fragmented natural areas.

The key to successful wildlife management is to include both ecological and human dimensions (KEULING et al. 2016) into the decision making process in order to achieve positive impacts that are valued by all stakeholders (RILEY et al. 2003). This is particularly true for the management of conflict species such as wild boar. Wild boar impacts can result in large costs and can be unacceptable for multiple stakeholders, with crop damage (including rooting in grasslands) as the primary impact (CAHILL et al. 2012). In the Netherlands, France, Luxembourg and Wallonia (Southern Belgium), the economic impact of crop damage by wild boar can be large (SCHLEY et al. 2008; CARNIS \& FACCHINI 2012; FAUNAFONDS 2014; WIDAR \& LUXEN 2016). In Flanders, compensation for wild boar damage is only paid by the authorities in the exceptional case where damage is done by wild boar originating from a nature reserve or forest where there is no hunting or culling program. In all other cases the hunter himself is responsible for paying for damage directly to the farmer. One of the consequences is that currently there is no centralised database covering damage paid annually. During annual meetings of wild boar management units, the need for better knowledge on the current extent of wild boar damage is stressed consistently by both farmers and hunters as well as nature administrators. Consequently there is an urgent need for a first assessment of current wild boar damage risk, its geographic distribution and factors driving it.

In this study, we aimed to assess:

- the probability of a farmer suffering wild boar damage given the current distribution of wild boar in Flanders.

- the spatial distribution of damage probability and factors influencing this distribution.

For this purpose, an online survey was implemented. Online surveys related to wildlife issues are used extensively as they can be easily implemented and they provide almost immediate results (STONE 1973; FREDERIK 1998; MOORE et al. 1999; REITER et al. 1999; LARD et al. 2002; SIGNORILLE \& EVANS 2007; WHITE et al. 2005). Online surveys are also an inexpensive data-collection method (DUDA \& NOBILE 2010; SEXTON et al. 2011) and sending an online survey by email allows for flexibility as respondents can participate when it is convenient (EvANS \& MATHUR 2005). Moreover, online surveys allow for direct data transfer into databases, eliminating manual input from questionnaires (EvANS \& MATHUR 2005; LEFEVER et al. 2007). However, online surveys also present some drawbacks that call for caution. 
RUTTEN A. et al., Wild boar crop damage assessment by online survey

Sample validity, respondent and stakeholder bias and unverified respondents could all lead to inaccurate, unreliable and biased results (White et al. 2005; DudA \& NOBILE 2010; EvANS \& MATHUR 2005, LEFEVER et al. 2007). Respondent bias occurs when the population of non-respondents differs from the respondent population. In this study respondent bias could have important consequences if farmers who had already suffered crop damage were more keen to respond than those that did not. Therefore we also conducted a non-respondent check.

\section{Material and methods}

\section{Study area}

At the onset of this study in 2015, the distribution of wild boar in Flanders was mostly limited to the province of Limburg (Fig. 1), i.e., the eastern part of Flanders near the Dutch border (SCHEPPERS et al. 2014). The geographical scope of this study was therefore limited to Limburg. With $23.6 \%$ of its surface area covered by forest, Limburg is the most forested province in Flanders (DEMOLDER et al. 2014; MoORs 2014), although still highly fragmented. Arable land in Limburg is dominated by maize (44.7\%), grassland (32.3\%) and cereal crops (23.0\%) (Flanders: 40.8\% - 38.0\% - 21.2\%) (report Federale Overheidsdienst Economie (FOD) 2015).

\section{Data collection}

\section{Online survey}

The online survey was conducted in collaboration with Boerenbond, the largest cooperative farmers' organisation in Flanders, who provided farmer contact details. Of the 2824 farmers in Limburg (data STATBEL), 1282 are members of Boerenbond, 904 of whom had a known email address. Since we expected no correlation between damage probability, Boerenbond membership and whether or not an email address was known, we assumed the sampling population as representative for the total Limburg

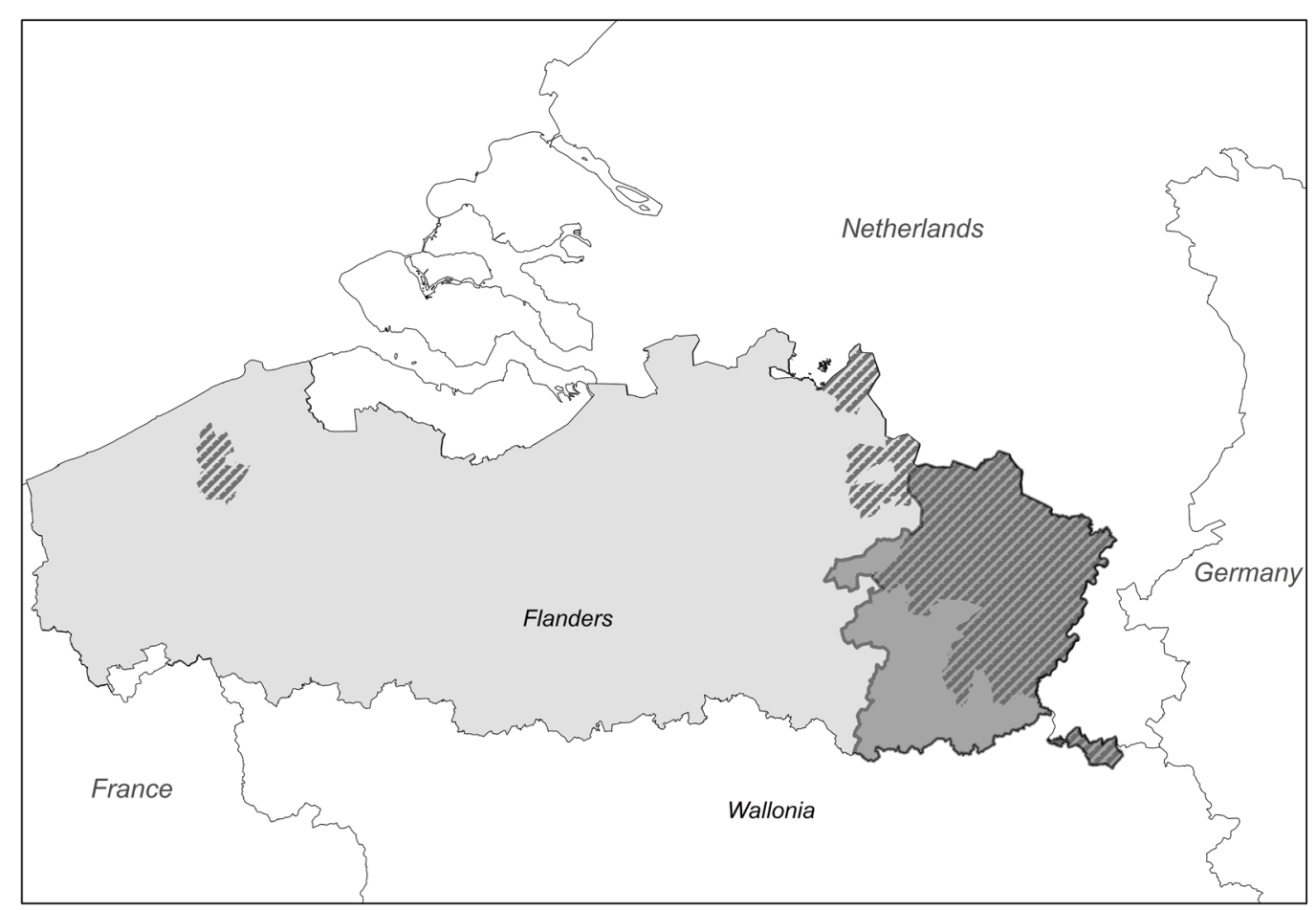

Fig. 1 - Study province of Limburg (dark grey), in the Northern part of Belgium (Flanders, light grey). Dashed lines: distribution area in Flanders of wild boar in 2014 (from hunting bag data (SCHEPPERS et al. 2014). 
farmer population. In order to avoid an unverified responder bias, typically linked to an open access online survey, we sent farmers a personal invitation using their email-address to participate. All farmers with a known email address received the online survey invitation in March 2015. Reminders were sent after one and after two weeks to increase the response rate. The survey consisted of eleven questions (see Appendix) and was estimated to take about 10 minutes to complete. Only the answers to three questions (damage/no damage, municipality and farm size) were used for this research.

\section{Non-Respondent check}

In our study we acknowledged the possibility that farmers who had suffered crop damage would be more keen to respond than would those who had not. Moreover, a non-respondent check should always be conducted in cases where low response rates are expected (DUDA \& NOBILE 2010; SEXTON et al. 2011). Therefore, for each of the 43 municipalities, we randomly selected three farmers among the non-respondents from the online survey, contacted them by telephone and asked two questions from the questionnaire used for this study (damage/no damage and farm size).

\section{Statistical analysis}

All analyses were performed using R software R CORE TEAM (2016).

\section{Survey sample}

A series of Kendal rank correlation tests were conducted. Firstly to control whether the distribution of the farmers who received the online survey matched the distribution over the different municipalities of the target population (all farmers of Limburg). Next, we tested the spatial representativeness of our respondents to the online survey by comparing the distribution over municipalities of respondents and the distribution of the entire Limburg farmer population. Also the distribution of farm sizes of the respondents was compared to the total distribution of farm sizes in the province of Limburg.

\section{Damage probability and its spatial distribution}

Damage probability was defined as the proportion of farms that had experienced damage over the total number of farms per municipality and these values were displayed on a map to visualise spatial patterns. We conducted a Chi-square test to see whether damage probability differed between those who answered the online survey and the participants of the non-respondent check.

\section{Factors influencing crop damage probability}

The following analyses were done both for the online survey and for the non-respondent check. Doing this parallel analysis, we were able to assess a potential respondent bias and its impact on our findings.

To explore the factors influencing crop damage probability, apart from farm size (which was included as an offset factor to account for size effects) and the random effect of municipality, four additional potential explanatory factors were selected (Table 1).

Forest cover was included as wild boar is a forest-dwelling species (BRIEDERMANN 1990). Previous research has also shown that forest cover influences wild boar distribution (MORELLE et al. 2016) and serves as a good predictor of crop damage (FICETOLA et al. 2014; LOMBARDINI et al. 2016). The percentage of arable land (agriculture cover) was included as it has been shown to be the most important factor next to population density and forest edge length in modelling crop damage probability (BLEIER et al. 2012). There are various suggested methods to estimate population densities of wild boar (FOCARDI et al. 2001, 2002; MASSEI et al. 1997; ACEVEDO et al. 2007), however finding a reliable method to estimate population densities at the municipality scale remains difficult (SCHEPPERS \& CASAER 2012; ENGEMAN et al. 2013). We therefore included both the number of years in which wild boar were shot in a given municipality over the period 2007-2014 (SCHEPPERS et al. 2014), and the number of wild boar shot in that period, as proxies for the abundance of wild boar. We consider these proxies as reliable given 
RUTTEN A. et al., Wild boar crop damage assessment by online survey

TABLE 1

Potential factors influencing crop damage probability.

\begin{tabular}{|c|c|c|}
\hline Variable & Abbreviation & Description \\
\hline Crop damage & $\mathrm{CD}$ & Did farmers experience damage (Yes-No) \\
\hline Farm size & FS & $\begin{array}{l}\text { Three categories such as used in the survey: } 0-40 \text { ha, } 40-60 \text { ha, } \\
>60 \text { ha }\end{array}$ \\
\hline Municipality & MUN & Municipality in which most of the cropland of the farm is situated \\
\hline Forest cover & $\mathrm{FC}$ & $\begin{array}{l}\text { Percentage of forest cover per municipality }(\text { mean }=21.1 \%, \mathrm{SE}= \\
13.1 \%)\end{array}$ \\
\hline Agriculture cover & $\mathrm{AC}$ & $\begin{array}{l}\text { Percentage of agriculture cover per municipality }(\text { mean }=43.5 \text {, } \\
\mathrm{SE}=20.8)\end{array}$ \\
\hline Years of hunting of wild boar & YH & $\begin{array}{l}\text { Number of years in which wild boar were shot in a municipality } \\
\text { over the period } 2007-2014(\text { mean }=2.74, \mathrm{SE}=0.15)\end{array}$ \\
\hline Number of wild boar shot & NS & $\begin{array}{l}\log (x+1) \text { of number of wild boar shot over the period } 2007-2014 \\
(\operatorname{mean}=11.9, \mathrm{SE}=1.9)\end{array}$ \\
\hline
\end{tabular}

that no temporal or spatial variation of culling or hunting effort was expected, no quotas for wild boar hunting exist, no large areas are exempted from hunting, and hunting takes place year-round.

We screened these four potential factors for collinearity combining Variance Inflation Factors (VIF) (FOX \& MONETTE 1992) in which we allowed a maximum VIF value of 2 and a correlation of which we set the maximum at 0.7 . This revealed that forest and agriculture cover were strongly negatively correlated. We opted to select forest cover in further analysis following the findings of (FICETOLA et al. 2014; LOMBARDINI et al. 2016). The number of years in which wild boar were shot and the number of animals shot were also highly correlated. We opted to include the number of wild boar shot as a factor in the model based on the fact that the number of years wild boar were shot showed the highest VIF (VIF = 5.19). The remaining factors forest coverage and number of wild boar shot had VIF values below 2 and a correlation below 0.7 .

We defined four linear mixed effect models for crop damage probability (Table 2). All models included farm size as an offset factor and the random effect of municipality. Model 1 was the null model in which no additional factors were included. In models 2 and 3 we additionally included forest cover or the number of wild boar shot respectively. Finally, in model 4, the full model, both forest cover and the number of wild boar shot were included.

AIC values (Akaike Information Criterion) Hu (2007) were used for model selection: in cases where the AIC values between two models differed by more than 2, the model with the lowest AIC values was selected as the best model. Effect size (mean divided by standard error) was calculated for each covariate in the final model. When the online survey and the non-respondent check would have comparable results, the AIC values should return the same a priori model, and the influence of covariates should be comparable.

\section{Results}

\section{Survey sample}

Of the 904 farmers contacted, 182 (20\%) completed the online survey and an additional 122 farmers were contacted by telephone for the non-respondent check. 


\section{TABLE 2}

Four a priori models. All models include Farm Size (FS) as an offset variable and the random effect of municipality $\left(\mathrm{f}_{\mathrm{MUN}}\right)$. Covariates Forest Cover (FC) and number of wild boar shot (NS) are also included in hypothesized model 2,3 and 4 .

\begin{tabular}{cc}
\hline Hypotheses & Model structure \\
\hline Model 1 & $\mathrm{CD} \sim \mathrm{FS}+\mathrm{f}_{\text {MUN }}$ \\
Model 2 & $\mathrm{CD} \sim \mathrm{FS}+\mathrm{FC}+\mathrm{f}_{\text {MUN }}$ \\
Model 3 & $\mathrm{CD} \sim \mathrm{FS}+\mathrm{NS}+\mathrm{f}_{\mathrm{MUN}}$ \\
Model 4 & $\mathrm{CD} \sim \mathrm{FS}+\mathrm{FC}+\mathrm{NS}+\mathrm{f}_{\mathrm{MUN}}$ \\
\hline
\end{tabular}

The correlation coefficient between the spatial distribution of the total population of farmers over the different municipalities in Limburg and the one of the members of the Boerenbond who received the survey was $0.95(\mathrm{p}<0.001)$. The correlation coefficient between the total population of farmers and farmers who responded to the online survey was $0.65(\mathrm{p}<0.001)$. The distribution of farm sizes among the online survey respondents was not correlated with that of the total population of farmers $(-0.84$, $\mathrm{p}>0.05$ ) as survey respondents included mostly smaller farm sizes.

\section{Damage probability and its spatial distribution}

We found that $42 \%$ ( 76 out of 182 ) of the respondents to the online survey reported damage, whereas only $22 \%$ (27 out of 122) of the non-respondents reported damage. Damage probability differed significantly between the two groups of respondents (online survey and non-respondent check) (chi-

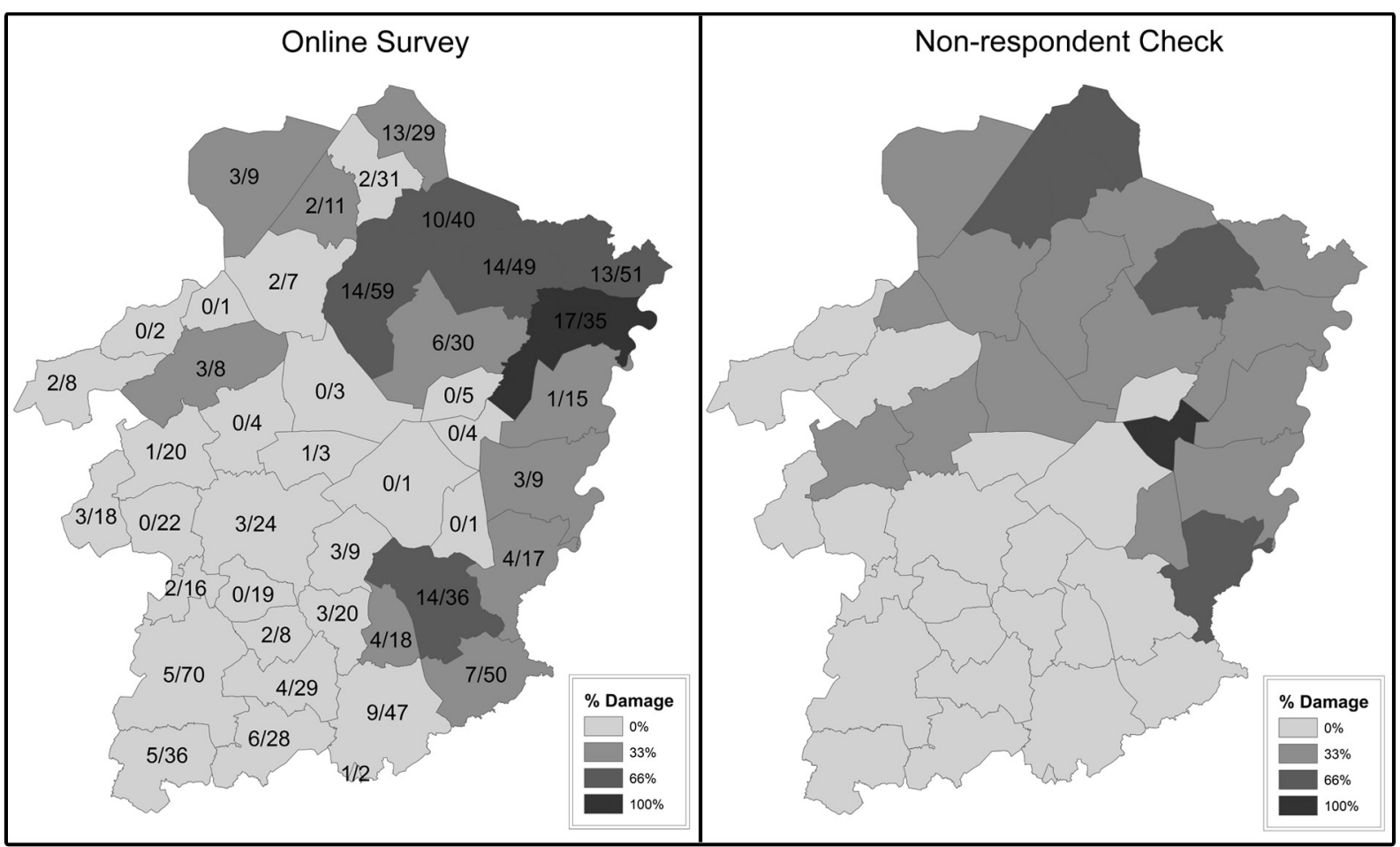

Fig. 2 - Spatial distribution of reported damage probability. Left: overview of number of farmers who responded to the online survey/who received the online survey; grey scale gradient represents percentage of reported damage. Right: percentage of damage reported in the non-respondent check with three contacted farmers per municipality. 
RUTTEN A. et al., Wild boar crop damage assessment by online survey

TABLE 3

Model selection. AIC (Akaike Information Criterion) and p-values of Log likelihood Test for all four a priori hypotheses. * is the selected model.

\begin{tabular}{ccccc}
\hline \multirow{2}{*}{ Hypotheses } & \multicolumn{2}{c}{ Online survey } & \multicolumn{2}{c}{ Non-respondent check } \\
\hline & AIC & p-value & AIC & p-value \\
Model 1 & 201,13 & & 115,77 & \\
Model 2 & 194,56 & 0,003 & $102.16^{*}$ & $<0.001$ \\
Model 3 & $180.99^{*}$ & $<0.001$ & 108,84 & 1 \\
Model 4 & 182,94 & 0,81 & 103,84 & 0,008 \\
\hline
\end{tabular}

square test, $\mathrm{p}<0.001)$. Therefore, spatial distribution maps were made separately for the online survey and the non-respondent check (Fig. 2). The highest reported damage prevalence was found in the north of the province of Limburg, according to both the online survey and the non-respondent check. Southern municipalities showed low to no damage probability.

\section{Factors influencing crop damage probability}

The model selection results are shown in Table 3. For the online survey, model 3 (including number of boars shot) was the most informative (lowest AIC value); for the non-respondent check, this was the case for model 2 (including forest cover). However, in both cases, the difference in AIC-values with model 4 (combining farm size with both hunting and forest cover) was very small $(<2)$ so the quality of that model is not significantly lower but model 4 showed forest cover to be non-significant for the online survey, and number of boars shot to be non-significant for the non-respondent check. Therefore, model 3 was selected as the best model for the online survey and model 2 for the non-respondent check.

Damage probability increases as farm size increases for both the model of the online survey and the nonrespondent check, confirming our size effect expectation (Table 4). For the online survey the number of boars shot was positively correlated with damage probability. The model for the non-respondent check showed increasing damage probability with increasing forest cover.

Predictions based on the final models (for intermediate farm size (40-60 ha), Fig. 3) show that according to the model from the online survey, the predicted crop damage probability increases considerably with
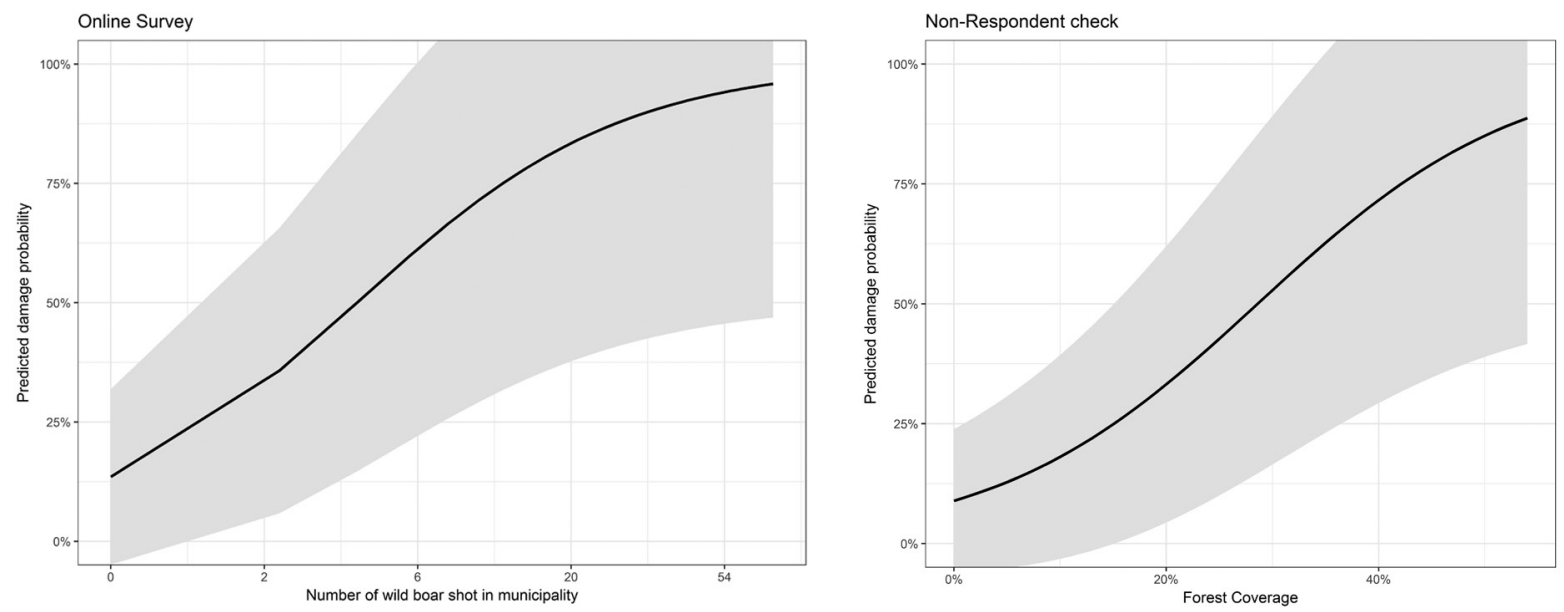

Fig. 3 - Prediction for damage probability based on final model of the online survey (left) and of the non-respondent check (right) for intermediate farm size (40-60 ha). 
TABLE 4

Model parameters of model 3 for the online survey and model 2 for the non-respondent check: Mean, standard error (SE), confidence intervals and effect size of the fixed effects describing the relationship between crop damage, farm size (FS), forest cover (FC) or number of wild boar shot (NS). * are significant parameters, $\mathrm{p}$-value $<0.05$.

\begin{tabular}{l|cccc|cccc}
\hline & \multicolumn{5}{|c|}{ Online survey } & \multicolumn{5}{c}{ Non-respondent check } \\
\hline & Mean & SE & $\begin{array}{c}\text { Effect } \\
\text { size }\end{array}$ & p-value & Mean & SE & $\begin{array}{c}\text { Effect } \\
\text { size }\end{array}$ & p-value \\
& & & & & & & & \\
Intercept & $-3,25$ & 0,76 & 4,28 & $<0.001^{*}$ & $-4,56$ & 0,83 & 5,49 & $<0.001^{*}$ \\
Farm Size: & & & & & & & & \\
$\quad$ FS 40-60 ha & 1,39 & 0,5 & 0,28 & $0.005^{*}$ & 2,23 & 0,69 & 3,23 & $0.001^{*}$ \\
$\quad$ FS $>60$ ha & 1,44 & 0,55 & 2,62 & $0.009^{*}$ & 2,14 & 0,68 & 3,15 & $0.001^{*}$ \\
Forest Coverage (FC) & $/$ & $/$ & $/$ & $/$ & 0,08 & 0,02 & 4 & $0.01^{*}$ \\
Number wild boar shot (NS) & 1,16 & 0,29 & 4 & $<0.001^{*}$ & $/$ & $/$ & $/$ & $/$ \\
\hline
\end{tabular}

a higher number of boars shot. According to the model from the non-respondent check, the damage probability curve increases with forest cover.

\section{Discussion}

As the socio-cultural context of wildlife management has changed in recent decades (RILEY et al. 2003), successful wildlife management more than ever implies including both ecological as well as human dimensions (KEULING et al. 2016). With wild boar causing more and more human-wildlife conflicts in Flanders, there was a need for a fast and simple method to collect information on the most important impact: crop damage. By using an online survey we aimed to gain an initial overview of the actual damage levels and their spatial distribution in the province of Limburg, Flanders.

Damage probability according to the online survey was $42 \%$, whilst the non-respondent check returned a lower damage probability of $22 \%$. We assume actual damage probability to be situated between these two values. As we consider farmers who already suffered crop damage to be more keen to respond than those that did not- introducing a respondent bias- we believe that the online survey resulted in an overestimation. However, we also consider the non-respondent check to be an underestimation as the surveyed population of this non-respondent check is based on farmers who did not respond to the online survey and consequently excludes those farmers who already experienced and reported crop damage using the online survey.

We consider the correlation between the spatial distribution of the online survey respondents and of the total farmer population high enough to be spatially representative of the population of interest. Both the online survey and the non-respondent check show a clear spatial differentiation of the crop damage risk within the province with northern municipalities showing higher damage probabilities compared to southern municipalities. These findings illustrate the usefulness of an online survey -although generally overestimating damage probability- to get a quick scan of the actual spatial distribution of damage in a region when no other information sources are available. These results on spatial distribution of crop damage were therefore used in the research of RUTTEN et al. (2018) to delineate a study area in which damage cases were photographed to develop a drone based method to objectively assess damaged area in a field.

The online survey and the non-respondent check models resulted in divergent conclusions with respect to factors explaining the crop damage probability. According to the online survey the number of wild 
RUTTEN A. et al., Wild boar crop damage assessment by online survey

boar shot can best explain damage probability while forest cover was not included in the final model. However, the model of the non-respondent check showed a clear positive effect of forest cover on damage probability and the effect of the number of wild boar shot was not retained in the final model. These opposite findings made us conclude that our approach does not allow any reliable conclusions to be drawn for this question.

Possible explanations for the opposite findings of the models may be our small sample size on the one hand and the correlation between forest coverage and the number of wild boar shot on the other hand; or a combination of both elements. The relation between increasing wild boar numbers with increasing forest coverage has been found in previous studies (BIEBER \& RUF 2005; MELIS et al. 2006). In our study, the correlation between forest coverage and number of wild boar shot was 0.68 . Given that this value is smaller than the set threshold value of 0.7 used for eliminating variables from the model building, both variables were included as factors in the model selection. Regarding the small sample size, we needed email addresses and telephone numbers of farmers, thus the collaboration with farmers' organisation Boerenbond was essential. This resulted in a total of 904 email-addresses, equalling $32 \%$ of the total farmer population in Limburg. However, we only achieved a response rate of $20 \%$ for the online survey.

While the goal of surveys like ours is to collect information beneficial for efficient management of human-wildlife conflicts (BROWNE-NUNEZ \& JONKER 2008), authors too often ignore the problem of respondent bias. According to a review on surveys in ecology by WHITE et al. (2005) only $12.5 \%$ of surveys included any form of non-respondent check. Studies like that of BARKER (1991) who did conduct such a check on the scope of hunter harvest of waterfowl in New Zealand, found that harvest estimates were about $20 \%$ higher according to respondents when compared to non-respondents; obviously, this can have large implications when bias is not accounted for when setting up survey-based harvest quotas. Potential consequences of not validating respondent bias also became clear in the present study: not only did factors influencing the spatial distribution differ between the online survey and the non-respondent check models, but we also found an overall higher damage probability according to predictions of the online survey model compared to the non-respondent check. This can lead to misguided conclusions and therefor misinformed decisions on management actions should they be based on these results only.

\section{Conclusions}

Using the online survey followed by a non-respondent check, we found clear spatial differentiation of crop damage risk within the province of Limburg; the online survey and the non-respondent check concurred in the geographic distribution of this risk. However we could not determine unambiguously the factors influencing damage probabilities as we found opposite results between the online survey and the non-respondent check. For future studies we recommend caution with the use of online surveys, certainly in cases where the risk for a low response rate is high. We suggest a focus on increasing sample size as much as possible. This can be achieved by providing rewards for completing the survey, persuading respondents that their responses will be used, providing frequent reminders, keeping the survey short or enhancing the survey with visual elements (NULTY 2008; DEUTSKENS et al. 2004). However, we want to stress that at all times a non-respondent check should be conducted to assess the validity of online survey results.

\section{Acknowledgements}

We would like to thank Boerenbond for its cooperation and for providing contact details on farmers in the region. We also thank the Flemish Land Agency (VLM) for the data on the distribution of farms across municipalities in Limburg. We are very grateful to all the farmers who participated in the surveys. We are grateful to Kris Somers and Sebastien Lizin from Hasselt University for the setup of the online survey, data collection and preliminary analysis. Finally, we want to express our appreciation to dr. Dirk Maes, dr. Lucida Kirkpatrick, Bram Vanden Broecke, Frederik Van de Perre and Emma Cartuyvels for their valuable advice on the manuscript. 


\section{References}

Acevedo P., Vicente J., Höfle U., CAssenello J., Ruiz-Fons F. \& Gortazar C. (2007). Estimation of European wild boar relative abundance and aggregation: a novel method in epidemiological risk assessment. Epidemiology and Infections 135 (3): 519-527. https://doi.org/10.1017/S0950268806007059

BARKER R. J. (1991). Nonresponse bias in New Zealand Waterfowl harvest surveys. The Journal of Wildlife Management 55 (1): 129-131. https://doi.org/10.2307/3809249

BIEBER C. \& RUF T. (2005). Population dynamics in wild boar Sus scrofa: ecology, elasticity of growth rate and implications for the management of pulsed resource consumers. Journal of Applied Ecology 42: 1203-1213. https://doi.org/10.1111/j.1365-2664.2005.01094.x

BleIER N., LEHOCSKI R., ÚJVÁRY D., SZEMETHY L. \& CSANYI S. (2012). Relationships between wild ungulates density and crop damage in Hungary. Acta Theriologica 57: 351-359.

https://doi.org/10.1007/s13364-012-0082-0

BRIEDERMANN L. (1990). Schwarzwild. Berlin, Germany.

Browne-NuñEZ C. \& JonkeR S. A. (2008). Attitudes Toward Wildlife and Conservation Across Africa: A Review of Survey Research. Human Dimensions of Wildlife 13 (1): 49-72. https://doi.org/10.1080/10871200701812936

Cahill S., Llimona F., CABañeros L. \& CAlomardo F. (2012). Habituation of wild boar (Sus scrofa) to urban areas: traits from Collserola Natural Park (Barcelona) and comparison with other cities. Animal Biodiversity and Conservation 35 (2): 221-233.

CARNIS L. \& FACCHINI F. (2012). Une approche économique des dégâts de gibier. Indemnisation, prix et propriété. In: Économie rurale, janvier-mars: 126-142.

Available from https://journals.openedition.org/economierurale/3326 [accessed 22 March 2019].

CARTER N.H. \& Linell J.D.C. (2016). Co-Adaptation Is Key to Coexisting with Large Carnivores. Trends in Ecology \& Evolution 31 (8): 575-578. https://doi.org/10.1016/j.tree.2016.05.006

CASAER J. \& LiCOPPE A. (2010). Ungulates and their management in Belgium. In: Apollonio M., Putman R. \& Andersen R. (eds) European Ungulates: 184-200. Cambridge University Press, Cambridge.

Demolder H., Schneiders A., Spanhove T., Maes D., Van Landuyt W. \& Adriaens T. (2014). Hoofdstuk 4: Toestand biodiversiteit. In: Natuurrapport - Toestand en trend van ecosystemen en ecosysteemdiensten in Vlaanderen: 1-83. Available from https://pureportal.inbo.be/ [accessed on 3 January 2017].

Deutskens E., De Ruyter K., Wetzels M. \& Oosterveld P. (2004). Response rate and response quality of internet-based surveys: An experimental study. Marketing letters 15 (1): 21-36. https://doi.org/10.1023/B:MARK.0000021968.86465.00

DudA M.D. \& NoBILE J.L. (2010). The Fallacy of Online Surveys: No Data Are Better Than Bad Data. Human Dimensions of Wildlife: 15: 55-64. https://doi.org/10.1080/10871200903244250

Engeman R.M., Massei G., Sage M. \& Gentle M.N. (2013). Monitoring wild pig populations: a review of methods. Environmental Science and Pollution Research 20: 8077-8091. https://doi.org/10.1007/s11356-013-2002-5

Evans J.R. \& MATHuR A. (2005). The value of online surveys. Internet Research 15: 195-219. https://doi.org/10.1108/10662240510590360

FAUNAFONDS. (2014). Jaarverslag Faunafonds: 2014: 4-54.

Available from https://www.bij12.nl/assets/Jaarverslag-Faunafonds-2014.pdf [accessed on 22 March 2019]. 
RUTTEN A. et al., Wild boar crop damage assessment by online survey

Ficetola G.F., Bonardi A., Mairota P., Leronni V. \& PAdoA-Schioppa E. (2014). Predicting wild boar damages to croplands in a mosaic of agricultural and natural areas. Current Zoology 60 (2): 170179. https://doi.org/10.1093/czoolo/60.2.170

FoX J. \& MONETTE G. (1992). Generalized collinearity diagnotics. Jounal of the American Statistical Association: 87 (417): 178-183. https://doi.org/10.1080/01621459.1992.10475190

FoCARDi S., DE MARINIS A. M., RizzotTo M. \& PUCCI A. (2001). Comparative evaluation of thermal infrared imaging and spotlighting to survey wildlife. Wildlife Society Bulletin 29 (1): 133-139.

FoCARDI S., ISOTTI R. \& TINELLI A. (2002). Line transect estimates of ungulate populations in a Mediterranean forest. The Journal of Wildlife Management 66 (1): 48-58.

https://doi.org/10.2307/3802870

FREDERIK J.M. (1998). Overview of wild pig damage in California. In: Baker R.O. \& Crabb A.C. (eds) Proceedings of the Eighteenth Vertebrate Pest Conference (1998): 82-86. University of California, Davis.

HU S. (2007). Akaike information criterion. Center for Research in Scientific Computation: 93.

Keuling O., Strauss E. \& Siebert U. (2016). Regulating wild boar populations is "somebody else's problem"! - Human dimension in wild boar management. Science of the Total Environment: 554-555, 311-319. https://doi.org/10.1016/j.scitotenv.2016.02.159

LARD C., WiLlis D.B., SALIN V. \& RoBisON S. (2002). Economic assessments of red imported fire ant on Texas' urban and agricultural sectors. Southwestern Entomologist 25: 123-137.

LefeVer S., DAl M. \& MATthiasdottiR A. (2007). Online data collection in academic research: advantages and limitations. British Journal of Educational Technology 38: 574-582.

Linell J.D.C., Swenson J.E. \& ANDERSEN R. (2001). Predators and people: conservation of large carnivores is possible at high human densities if management policy is favourable. Animal Conservation 4: 345-349. https://doi.org/10.1017/S1367943001001408

LOMBARDini M., MERIGGi A. \& FozZI A. (2016). Factors influencing wild boar damage to agricultural crops in Sardinia (Italy). Current Zoology: 63 (5): 507-517. https://doi.org/10.1093/cz/zow099

MASsei G., Genov P.V., Staines B.W. \& Gorman M.L. (1997). Factors influencing home range and activity of wild boar (Sus scrofa) in a Mediterranean coastal area. The Zoological Society of London: 242: 411-423. https://doi.org/10.1111/j.1469-7998.1997.tb03845.x

Massei G., Kindberg J., Licoppe A., Gacic D., Sprem N., Kamler J., Baubet E., Hohmann U., Monaco A., Ozolins J., Cellina S., Podgorski T., Fonseca C., Markov G., Pokorny B., Rosell C. \& NAHLIK A. (2015). Wild boar populations up, numbers of hunters down? A review of trends and implications for Europe. Pest Management Science 71: 492-500.

https://doi.org/10.1002/ps.3965

MElis C., SZAFranska P.A., JedRZEJEWSKe B. \& BARTON K. (2006). Biogeographical variation in the population density of wild boar (Sus scrofa) in western Eurasia. Journal of biogeography 33: 803-811. https://doi.org/10.1111/j.1365-2699.2006.01434.x

Moore N., Whiterow A., Kelly P., Garthwaite D., Bishop J., Langton S. \& Cheeseman C. (1999). Survey of badger Meles meles damage to agriculture in England and Wales. Journal of Applied Ecology 36: 974-988. https://doi.org/10.1046/j.1365-2664.1999.00454.x

Moors I. (2014). De Limburgse Land- en Tuinbouw in Kaart: Analyserapport: 1-34. De deputatie van de provincieraad van Limburg, Hasselt.

Morelle K., Fattebert J., Mengal C. \& Lejeune P. (2016). Invading or recolonizing? Patterns and drivers of wild boar population expansion into Belgian agroecosystems. Agriculture Ecosystems \& Environment 222: 267-275. https://doi.org/10.1016/j.agee.2016.02.016

NuLTY D.D. (2008). The adequacy of response rates to online and paper surveys: what can be done? Assessment \& Evaluation in Higher Education 33:301-314.https://doi.org/10.1080/02602930701293231 
R Core TEAM. (2016). R: A language and environment for statistical computing. R Foundation for Statistical Computing, Vienna, Austria.

Reiter D.K., Brunson M.W. \& SCHMidT R.H. (1999). Public attitudes towards wildlife damage management and policy. Wildlife Society Bulletin 27 (3): 746-758.

Riley S.J., Siemer W., Decker D., Carpenter L., Organ J. \& Berchielli L. (2003). Adaptive Impact Management: An Integrative Approach to Wildlife Management. Human Dimensions of Wildlife 8: 81-95. https://doi.org/10.1080/10871200304301

Rutten A., Casaer, J. Vogels M.F.A., Addink E.A., Vanden Borre J. \& Leirs H. (2018). Assessing agricultural damage by wild boar using drones. Wildlife Society Bulletin 42 (4): 568-576. https://doi.org/10.1002/wsb.916

SaEZ-Royuela C. \& Telleria J.L. (1986). The increased population of the Wild Boar (Sus scrofa L.) in Europe. Mammal Review 16 (2) 97-101. https://doi.org/10.1111/j.1365-2907.1986.tb00027.x

SCHEPPERS T. \& CASAER J. (2012). Overzicht van mogelijke telmethoden voor everzwijn. INBO rapport: 1-40. Available from https://pureportal.inbo.be/ [accessed on 17 March 2017].

Scheppers T., Huysentruyt F., Neukermans A., Vercammen E., Verschaffel E. \& Casaer J. (2014). Grofwildjacht in Vlaanderen - Cijfers en statistieken 2013. INBO rapport, INBO, Brussels. Available from https://pureportal.inbo.be/ [accessed on 17 March 2017].

SCHLEY L., DufrênE M., KRIER A. \& FrantZ A.C. (2008). Patterns of crop damage by wild boar (Sus scrofa) in Luxembourg over a 10-year period. European Journal of Wildlife Research 54 (4): 589-599. https://doi.org/10.1007/s10344-008-0183-x

SeXton N.R., Miller H.M. \& Dietsch A.M. (2011). Appropriate uses and considerations for online surveying in human dimensions research. Human Dimensions of Wildlife 16 (3): 154-163.

https://doi.org/10.1080/10871209.2011.572142

SigNORILLEA.L. \& EVANS J. (2007). Damage caused by the American grey squirrel (Sciurus carolinensis) to agricultural crops, poplar plantations and semi-natural woodland in Piedmont, Italy. Forestry 80 (1): 89-98. https://doi.org/10.1093/forestry/cp1044

STONE C.P. (1973). Bird damage to agricultural crops in the United States - a current summary. Bird Control Seminars Proceedings 1: 263-267.

Treves A., Wallace R.B., Naughton-Treves L. \& Morales A. (2006). Co-managing human-wildlife conflicts: A Review. Human Dimensions of Wildlife 11: 383-396. https://doi.org/10.1080/10871200600984265

TROUWBorst A. (2010). Managing the carnivore comeback: international and EU species protection law and the return of lynx, wolf and bear to Western Europe. Journal of Environmental Law 22 (3): 347-372. https://doi.org/10.1093/jel/eqq013

White P.C.L., JENNINGS N.V., RENWICK A.R. \& BARKER N.H.L. (2005). Questionnaires in ecology: a review of past use and recommendations for best practice. Journal of Applied Ecology 42: 421-430. https://doi.org/10.1111/j.1365-2664.2005.01032.x

WIDAR J. \& LUXEN P. (2016). Statistiques de dégâts agricoles de la faune sauvage, issues des données des experts : évolution de 2008 à 2014. Fourrages mieux: 1-124.

Manuscript received: 17 June 2018

Manuscript accepted: 27 December 2018

Published on: 12 April 2019

Branch editor: Johan Michaux 


\section{Appendix}

\section{Online survey}

1. In which agricultural sector is your farm situated?
a. Cattle farming
e. Fruit culture
b. Pig farming
f. Vegetable cultivation
c. Chicken farming
g. Floriculture
d. Arable farming
h. Others

2. In which municipality is the largest part of the farm situated?

$$
\text { Fill in }
$$

3. What is the total surface of your farm?
a. $0-10$ ha
d. $40-60$ ha
b. $\quad 10-20$ ha
e. More than 60 ha

4. Do you have crops which can be sensitive for wild boar damage (grasslands are regarded as crops)?
a. Yes
b. No

5. Did you already experience damage by wild boar?

a. Yes

b. No

6. Which crops have already been damaged?
a. Grassland
b. Wheat
g. Maize
c. Rye
d. Barley
e. Triticale
h. Sugar beets
i. Potatoes
j. $\quad$ Fodder beets

7. What is the damaged surface for each of the damaged crops?

Fill in

8. Did you already take preventive measures to prevent damage from wild boar? And which ones did you take? Fill in

9. Did you already request damage compensation?
a. Yes
b. No

10. Why did you not request damage compensation? Fill in

11. Score the following statements

a. I would take preventive measures because:

\begin{tabular}{|l|l|l|l|l|l|}
\hline & $\begin{array}{c}\text { I totally } \\
\text { agree }\end{array}$ & I agree & Neutral & $\begin{array}{c}\text { I do not } \\
\text { agree }\end{array}$ & $\begin{array}{c}\text { I totally do } \\
\text { not agree }\end{array}$ \\
\hline $\begin{array}{l}\text { I think the damage compensation in Flanders is insufficient } \\
\text { I don't think the current hunting pressure has a positive effect on the } \\
\text { population }\end{array}$ & & & & & \\
\hline Wild boar numbers and damage will increase & & & & & \\
\hline Investing in preventive measures is advantageous & & & & & \\
\hline I don't have to worry about future damage & & & & & \\
\hline I can prevent discussions with hunters and other farmers & & & & \\
\hline
\end{tabular}

b. I don't take preventive measures because:

\begin{tabular}{|l|l|l|l|l|l|}
\hline & $\begin{array}{c}\text { I totally } \\
\text { agree }\end{array}$ & I agree & Neutral & $\begin{array}{c}\text { I do not } \\
\text { agree }\end{array}$ & $\begin{array}{c}\text { I totally } \\
\text { do not } \\
\text { agree }\end{array}$ \\
\hline There are no wild boar in this area & & & & & \\
\hline There is no damage in this area & & & & & \\
\hline The investment is too high compared to the damage & & & & & \\
\hline Measures should be taken by hunters, not by farmers & & & & \\
\hline Measures should be taken by owners of nature areas, not by farmers & & & & & \\
\hline
\end{tabular}

